Original research article

\title{
Obstructive sleep apnea syndrome and high-risk pregnancy
}

\author{
Jana Hudecova $^{1 *}$, Petr Hosek ${ }^{2}$, Bretislav Gal ${ }^{3}$, Ondrej Trcka ${ }^{4}$, Tomas Kostlivy ${ }^{4}$, Jaroslav Betka ${ }^{5}$, \\ Martina Baneckova ${ }^{6}$, Gabriela Krakorova ${ }^{7}$ \\ ${ }^{1}$ Charles University, Faculty of Medicine in Pilsen, Department of Gynaecology and Obstetrics, Charles University in Prague, Pilsen, Czech Republic \\ ${ }^{2}$ Charles University in Prague, Faculty of Medicine in Pilsen, Biomedical Center, Pilsen, Czech Republic \\ ${ }^{3}$ Masaryk University, Faculty of Medicine, Department of Otorhinolaryngology and Head and Neck Surgery, Brno, Czech Republic \\ ${ }^{4}$ Charles University, Faculty of Medicine in Pilsen, Ear, Nose and Throat Department, Pilsen, Czech Republic \\ ${ }^{5}$ Charles University in Prague, 1st Faculty of Medicine, Department of Otorhinolaryngology and Head and Neck Surgery, Prague, Czech Republic \\ ${ }^{6}$ Charles University, Faculty of Medicine in Pilsen, Department of Pathology, Charles University in Prague, Pilsen, Czech Republic \\ ${ }^{7}$ Charles University, Faculty of Medicine Pilsen, Pneumology Department, Pilsen, Czech Republic
}

\section{Abstract}

Introduction: According to the available data, OSAS (Obstructive Sleep Apnea Syndrome) occurs in the fourth decade in 1 to $5 \%$ of women in the total population, and over $90 \%$ of women with OSAS do not know about their problems. Approximately $15 \%$ of obese pregnant females are thought to suffer from SAS. The aim of this work is to explore OSAS incidence in high-risk pregnant women and the association of OSAS with risk factors for pregnancy.

Material: 85 women of a group of 480 monitored high-risk pregnant females were examined, and 61 of these were involved in this study. Methods: We statistically evaluated the relation between OSAS and hypertension, obesity, preeclamptic placental changes, low pH values of umbilical cord blood, and low PlGF levels in the group of high-risk pregnant women with AHI $<5$ and in the group with AHI $\geq 5$.

Results: In the monitored group there was a statistical significant coherence between OSAS and gestational diabetes and obesity in high-risk gravid women. Surprisingly, an association with hypertension was not found. From a statistical point of view, evaluations of histomorphological preeclamptic placental changes, low $\mathrm{pH}$ values of umbilical cord blood and low PlGF levels was not significant for a small number of respondents with these disorders.
\end{abstract}

Keywords: High-risk pregnancy; Hypertension; Obesity; OSAS; Preeclampsie

\section{Introduction}

According to epidemiologic studies, sleep breathing disorders affect approximately $15 \%$ of the population (Slouka et al., 2015). About half of these disorders are caused by sleep apnea syndrome (SAS). This syndrome is divided into three forms: obstructive (OSAS), central and mixed. The seriousness of sleep apnea syndrome is definitely assessed in accordance with an average number of breathing events per hour of sleep (apnea-hypopnea index, AHI): mild SAS (AHI 5-14.9), moderate (AHI 15-29.9) and severe (AHI $\geq 30$ ) (Sonka and Nevšímalová, 2011).

Sleep breathing disorders related to OSAS are associated with cardiovascular disorders (Monahan and Redline, 2011). OSAS may cause hypertension or complicate its treatment. Myocardial infarction, heart failure, cerebral vascular events, as well as a higher probability of recurrent atrial fibrilation after successful cardioversion essentially rank among other related cardiovascular disorders (Kasai, 2012). The risk of cardio- vascular events in patients with non-treated SAS is three times higher than in the common population (Barbé et al., 2012).

Other common symptoms and complications of OSAS include memory and concentration disorders, daytime sleepiness, nocturnal polyuria and worsened response to treatment of diabetes (Slouka et al., 2015). Poor quality of life in patients with non-treated severe OSAS is connected with social aspects (Slouka et al., 2018).

Endocrine and metabolic disorders associated with OSAS are among the lesser-known disturbances. Changes in the endocrine system and metabolism (Slouka et al., 2015) influence the hypertrophy of tissues (as well as space in the upper airways) and breathing control. Fragmented sleep causes lower secretion of the growth hormone (Xu et al., 2018) and decreases testosterone levels (Cho and Duffy, 2017). Some epidemiologic studies show that a decrease in progesterone and estrogen levels after the menopause is directly connected with a higher risk of OSAS (Polo-Kantola et al., 2003). Coherence between hypothyreosis and OSAS has not been sufficiently proven up to now, even if clinical experience with OSAS im-

\footnotetext{
* Author for correspondence: Jana Hudecova, Faculty of Medicine in Pilsen, Department of Gynaecology and Obstetrics, Alej Svobody 80, 32301 Pilsen, Czech Republic, e-mail: hudecovaja@fnplzen.cz http://doi.org/10.32725/kont.2019.043

Submitted: 2019-02-08 • Accepted: 2019-08-21 • Prepublished online: 2019-10-03 
provement after compensated hypothyreosis is mentioned (Slouka et al., 2015), thyreopathic myositis makes muscular functions (including airway dilators) worse and submucosal deposition of mucoproteins also causes narrowing of the upper airways. There are different opinions on the relationship between Cushing's syndrome (hypercorticolism) and apnea (Shipley et al., 1992). Nocturnal polyuria, mentioned above, is associated with higher secretion of atrial natriuretic peptide and decreased activity of the renin-angiotenzin-aldosteron system (Tanaka et al., 2017). Subsequent higher sodium secretion may be one of the co-factors related to OSAS impact on hypertension (Tsuda, 2017). Sleep breathing disorders bring about increased catecholamine excretion and a higher activity of the sympathicus, leading to hyperinsulinemia as well as potencing hypertension (Slouka et al., 2014).

Continuous positive airway pressure (CPAP) is considered to be first-line therapy in patients with moderate and severe OSAS. It takes effect very quickly in the common population if treatment is performed successfully. Over the course of several weeks, we can see considerable subjective (feeling of rest after nocturnal sleep) and objective improvements of OSAS (reduction of breathing events and hyposaturation) (Slouka et al., 2018).

According to the available data, OSAS occurs in the fourth decade in 1 to $5 \%$ of women in the total population, and over $90 \%$ of women with OSAS do not know about their problems (Redline et al., 1994; Young, 1993).

OSAS affecting pregnant females has not been sufficiently explored until now. The presence of OSAS in women of reproductive age is often underdiagnosed (Bixler et al., 2001). The real and objectively documented prevalence of OSAS in gravid women is not known so far. However, approximately $15 \%$ of obese pregnant women are thought to suffer from SAS (Louis et al., 2012). Polysomnographically documented studies show that OSAS is associated with pathologies related to a higher incidence of preeclampsia (Champagne et al., 2009; Iczi et al., 2005; Ursavas et al., 2008).

The aim of this work is to detect OSAS incidence in highrisk pregnant females and the statistical relationship between OSAS incidence and risk factors, such as gestational hypertension, diabetes mellitus (GD, Gestational Diabetes), obesity, histomorphological preeclamptic placental changes, low $\mathrm{pH}$ values of umbilical cord blood, and low PlGF levels (Placental Growth Factor). If these findings are positive, it will be necessary to adjust the scheme of taking care of high-risk pregnant patients with respect to early diagnosis of OSAS as a factor increasing the occurrence of health complications in these patients. Our next aim will be to identify these patients early, set the way of care and to prove adequate decrease in their perinatal morbidity up to the level identical to that of mothers without OSAS, in a similar way to PAP administration in patients with SAS (Pien et al., 2005).

\section{Materials and methods}

\section{Materials}

A group of 480 high-risk pregnant patients monitored in the Department of Gynaecology and Obstetrics in Pilsen from 2014 to 2016 were used for the purpose of this study. 85 women from this group were involved in the research. 24 women did not meet the classification criteria and had to be excluded. The final studied group included 61 women (Group 1 and Group 2) (Table 1).

\begin{tabular}{|c|c|c|c|}
\hline High-risk pregnant females & 480 & & Age \\
\hline Involved patients & 85 & & \\
\hline Used group & 61 & $100,0 \%$ & $31.09 \pm 5.83$ \\
\hline AHI $\geq 5$ (Group 1$)$ & 21 & $34,4 \%$ & $33.0 \pm 5.62$ \\
\hline AHI $<5$ (Group 2) & 40 & $65,6 \%$ & $30.1 \pm 5.77$ \\
\hline
\end{tabular}

Classification criteria: high-risk pregnancy, screening records of nocturnal sleep, complete records of input data including BMI, changes in blood pressure (normotension, pregestational and gestational hypertension), gestational diabetes mellitus and perinatal and neonatal outcome.

Elimination criteria: multiple pregnancy, non-valid screening records of nocturnal sleep, poor cooperation and missing input data.

\section{Methods}

This work is a monocentric prospective cohort study dealing with the group of high-risk pregnant women. Commonly measured data were compared between the sample of patients with and without OSAS. The aim of the work was to create a prospective study with subsequent statistical evaluation. This statistical assessment was calculated with respect to the total of 61 patients included in the study. The patients' personal data was only accessed by authorized medical staff and it was completely anonymized before the evaluation.

The following variables were recorded and analysed:

Hypertension was defined as blood pressure above 140/90 during two measurements over the course of 6 hours or if systolic pressure increased by $30 \mathrm{mmHg}$ and diastolic pressure was rising by $15 \mathrm{mmHg}$ (WHO, 1999).

BMI (Body Mass Index) was defined as body weight divided by the height squared; a measure of the degree of obesity.

AHI (apnea-hypopnea index) was defined as the average number of apnea and hypopnea during one hour of sleep.

Histomorphological (preeclamptic) placental changes were defined as placental spiral arteries vasculopathy with atherosis causing limited vascular flow and partial placental infarction.

Low $\mathrm{pH}$ value (potential of hydrogen) of umbilical cord blood was defined as $X \leq 7.25$.

Low PlGF level (placental growth factor) was defined as $X<12$.

The Ethics Committee of the University Hospital Pilsen granted the approval of the data analyses.

\section{Statistical methods}

\section{Basic statistics}

The Shapiro-Wilk test shows significantly non-normal distributions of most quantitative variables. Non-parametric tests were used for the subsequent analysis. The tested relationship between AHI parameters and age, BMI, GDM, histomorphological placental changes, low PlGF levels and low $\mathrm{pH}$ values were compared between the women's groups with $\mathrm{AHI} \geq 5$ and AHI $<5$ by carrying out the Mann-Whitney $U$ test. Mutual correlations between the quantitative variables were analysed using the Spearman's correlation coefficient. All mentioned $p$-values were two-tailed and the level of statistical significance was set at $\alpha=0.05$. The basic statistical analysis was performed in STATISTICA (StatSoft, Inc.2013. Version 12. www.statsoft. com). 


\section{Results}

The Chart 1 shows that pregnant females with AHI $\geq 5$ (Group 1) are statistically significantly older than pregnant women of the group with AHI < 5 (Group 2).

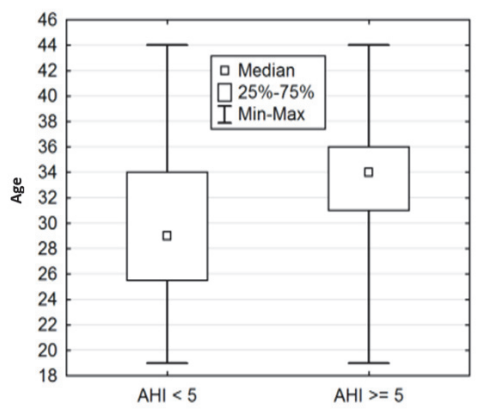

Chart 1. Coherence between the age of pregnant females and groups with $\mathrm{AHI} \geq 5$ and with $\mathrm{AHI}<5$
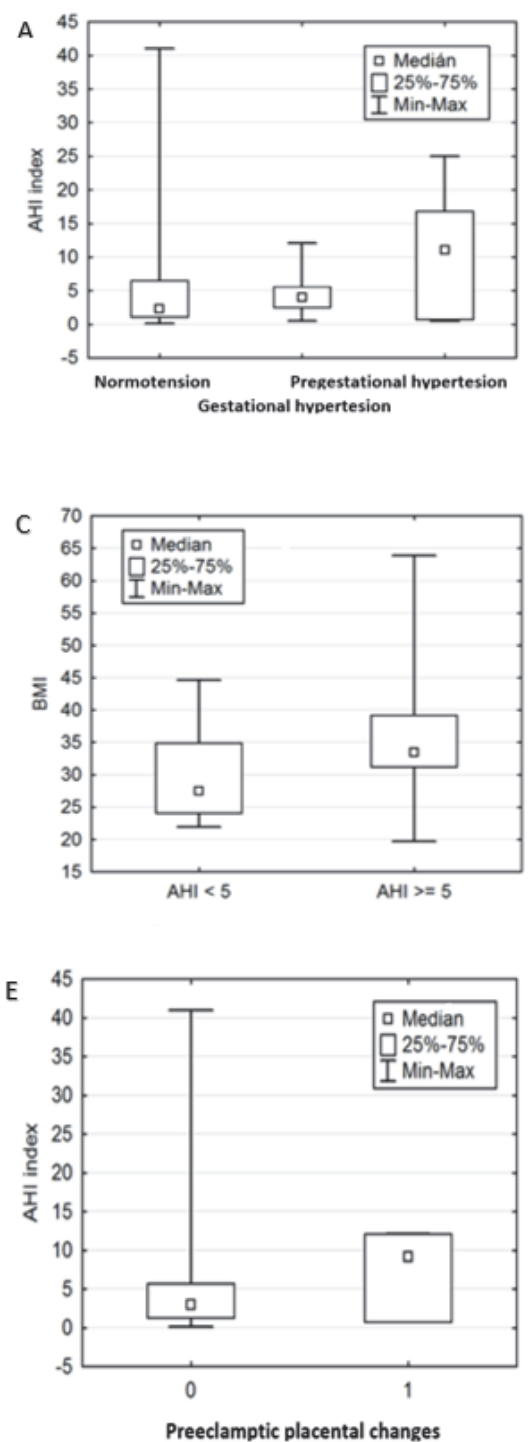

Regarding blood pressure examination in the first group $(\mathrm{AHI} \geq 5)$ of pregnant females with detected OSAS, we diagnosed normotension in ten gravid women, gestational hypertension in eight patients, and pregestational hypertension in three of them. In the other group (AHI < 5) of pregnant females without detected OSAS, there were twenty-five women with normotension, thirteen women with gestational hypertension and two women with pregestational hypertension. From a statistical point of view, there was no difference in both defined groups (Chart 2a).

GD (gestational diabetes mellitus requiring a diet or insulin therapy) was diagnosed in four women of the first group $(\mathrm{AHI} \geq 5)$. GD was detected in one patient of the other group $(\mathrm{AHI}<5)$. From a statistical point of view, this is a significant dependence of any GDM on AHI (Chart 2b). With regards to potential confounding related to obesity, the result is almost beyond the statistical significance due to a small number of pregnant females with detected GD; that is why it is not mentioned.

In the case of the first group ( $\mathrm{AHI} \geq 5$ ), sixteen patients had $\mathrm{BMI} \geq 30$, and five patients had $\mathrm{BMI}<30$. Regarding the
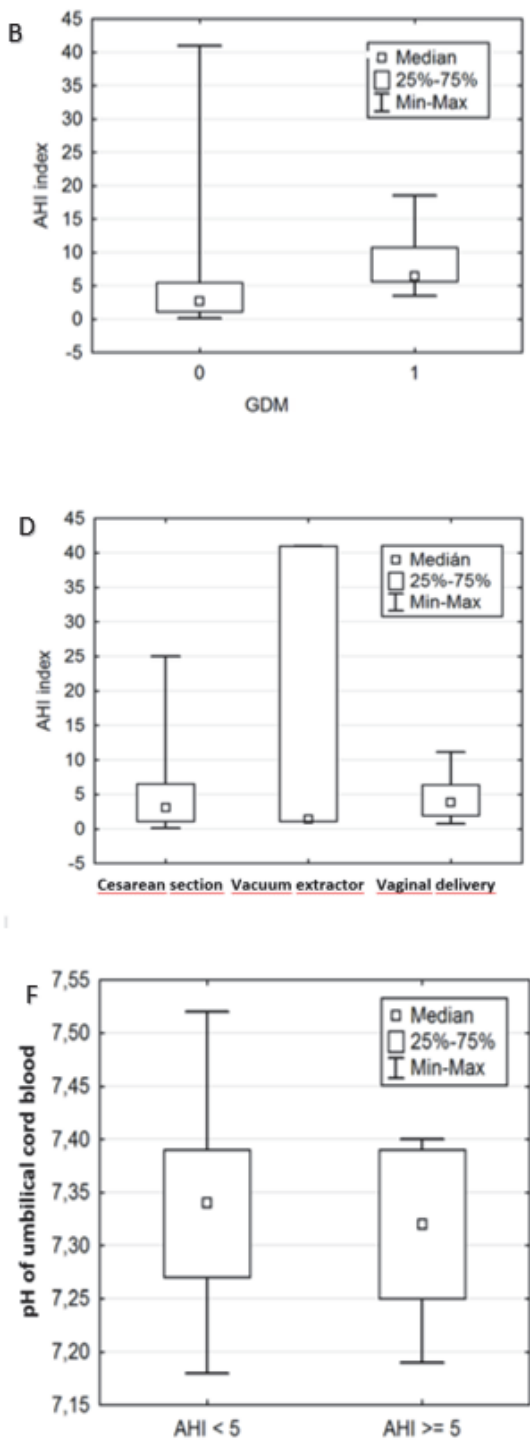

Chart 2. Coherence between (A) AHI and blood pressure; (B) AHI and any GD; (C) BMI and groups with AHI $\geq 5$ and with AHI < 5; (D) AHI and the way to end pregnancy; (E) AHI and histological preeclamptic changes; (F) low values of umbilical cord blood, and groups with AHI $\geq 5$ and with $\mathrm{AHI}<5$. 
other group $(\mathrm{AHI}<5)$, nineteen women had $\mathrm{BMI} \geq 30$ and twenty-one had BMI < 30. A statistically significant positive correlation was proved in relation to BMI and AHI (Chart 2c).

In terms of the method used to end the pregnancy, cesarean section was performed twelve times, the vacuum extractor was used once, and seven women delivered vaginally in the first group ( $\mathrm{AHI} \geq 5)$. In the other group (AHI $<5$ ), pregnancy was ended by performing cesarean section in twenty-two patients, twice by using the vacuum extractor, and eleven women delivered vaginally. From a statistical point of view, there was no substantial difference in both groups (Chart 2d).

Histomorphological preeclamptic changes were detected in two patients of the first group with OSAS. In the case of the other group (without diagnosed OSAS), placental changes were only found in one patient. According to the statistical evaluation, there was no significant difference in both groups for a very small number of affected placentas (Chart 2e).

The $\mathrm{pH}$ values of umbilical cord blood were only monitored in thirty-six of sixty-one pregnant women involved in the study. For technical reasons, related results were not available in the other ones. In the first group (AHI $\geq 5$ ), low $\mathrm{pH}$ was detected in four pregnant women out of the fifteen observed. In the other group (AHI < 5), low $\mathrm{pH}$ was only found in two of twenty-one women. According to the statistical evaluation, this equates to no significant dependence (Chart 2f).

PIGF levels were tested in forty-nine of the sixty-one pregnant women involved in the study. These values were not examined in twelve patients for technical reasons. Very low PlGF levels were only measured in four patients of both groups. No significant difference was proved in a statistical way.

\section{Discussion}

The incidence of high-risk pregnancies is increasing, resulting in more demanding care for these patients. This is followed by indirectly increasing costs of this care (Liu et al., 2009). At the same time, OSAS occurrence increases in pregnant females (Bourjeily et al., 2010). Some authors mention that OSAS affects more than one third of women during the third trimester of pregnancy (Duley, 2009), which corresponds to the findings related to our group where OSAS occurred in $34.4 \%$. In the course of the last few years, we can also see a rising frequency of risk factors in pregnant females leading to preeclampsia. Early detection of risk factors, detection of preeclampsia and subsequent treatment are not only prevention against serious complications, such as organ affection (e.g. liver or kidneys), but also against mothers' death or fetal damage (Högberg, 2005). Another crucial fact is the high risk of cardiovascular diseases in mothers with preeclampsia (O'Brien et al., 2014). That is why subsequent education on appropriate changes in lifestyle related to eating, gradual loss of weight, motion activities and stress prevention is important. Education should be focused on the women who are put at high risk of cardiovascular diseases as well as on those ones who already suffer from one of these diseases (Olišarová et al., 2016).

In our compared groups (Group $1 \mathrm{AHI} \geq 5$ versus Group 2 $\mathrm{AHI}<5)$, there is a statistically significant age difference. After clinical correlation, this difference becomes less high and less important $(33.0 \pm 5.62$ versus $30.1 \pm 5.77)$ and does not influence the validity of results.

Blood pressure disorders affect approximately $10 \%$ of pregnant females and are factorsthat increase the risk of undesirable events during pregnancy (Duley, 2009). Surprisingly, we proved no difference of the statistical occurrence of hyperten- sion in high-risk pregnant women (with and without OSAS) in our group. Our conclusions differ from those of O'Brien et al. (2012), where the dependence of OSAS on gestational hypertension was proved in a large group of pregnant females. Reid et al. (2011) also came to similar conclusions to O'Brian. The results of O'Brien et al. (2012) and Reid et al. (2011) correspond, even with the clearly proven connection of OSAS to hypertension in the common population (Townsend et al., 2016). The difference between the statistical results is thought to have been caused by a larger number of respondents' in the compared group.

The result concerning the statistical independence of the occurrence of GD and OSAS was a surprising conclusion of the O'Brien study mentioned above (O'Brien et al., 2012). Their results do not correlate with diabetes mellitus (DM) and OSAS in the common population. The statistical relation between GD and OSAS was proved by a strong association between GD and OSAS in our work, and so it conforms with the study work of Reutrakul et al. (2013).

In the monitored group, we also explored the connection between obesity (BMI over 30) and OSAS within the completeness of results. A statistical significant dependence was proved in compliance with the study work of Olivarez et al. (2011). Considering overweight and obesity, hidden patterns of behaviour and motives (e.g. cultural conditionality of eating habits in pregnant women) may also be found in gravid women. Their identification can help them to lose weight (Olišarová et al., 2016).

The dependence of the way to end the pregnancy on OSAS was not proved in our group. Our results differ from the conclusion of Spence et al. (2017) who detected a higher probability of cesarean section to end the pregnancy in a group of 350 pregnant women. Nevertheless, the difference in results may arise from the fact that two groups of high-risk pregnant females with OSAS and without OSAS were compared in our group of patients, unlike the work of Spence et al. (2017) in which a common sample of the pregnant population with OSAS was statistically compared to a sample of risk-free pregnant patients.

Unfortunately, no available study has explored the occurrence of histomorphological changes, low $\mathrm{pH}$ values of umbilical cord blood (potential of hydrogen) and low PlGF levels in connection with OSAS. The detection of these disorders was so low in our group that statistical results could not be considered valid.

\section{Conclusions}

High-risk pregnancies increase the costs of medical care of these patients and make the occurrence of life-threatening health complications in mothers as well as children higher, too.

Our study detected a coherence between OSAS in high-risk gravid women and obesity and GD. Owing to the low occurrence, the association with OSAS related to histomorphological placental changes, low $\mathrm{pH}$ values of umbilical cord blood (potential of hydrogen) and low PlGF levels was not clarified in our patients. The conclusion will be completed and added after the number of new respondents involved in the study increases. Our results show the significance of education for common people in the prevention of obesity as a clear co-factor of OSAS and an increase in the probability of complications in high-risk pregnant women. This education should be aimed at patients at risk, as well as at people who have already been treated for some disease. 


\section{Acknowledgements}

This project was supported by the grant from the Ministry of Health of the Czech Republic - Conceptual Development of Research Organization (Faculty Hospital in Pilsen - FNPl, 00669806), and by the National Sustainability Program I (NPU I) Nr. LO1503 provided by the Ministry of Education Youth and Sports of the Czech Republic.

\section{Conflict of interests}

The authors have no conflict of interests to declare in this article.

\section{Syndrom obstrukční spánkové apnoe a vysoce rizikové těhotenství}

\section{Souhrn}

Úvod: Podle dostupných pramenů trpí syndromem obstrukční spánkové apnoe (OSAS) ve čtvrté dekádě života 1-5 \% ženské populace a více než $90 \%$ žen s OSAS o svém problému neví. Přibližně $15 \%$ obézních těhotných žen má pravděpodobně SAS (Sleep Apnoe Syndrome). Cílem práce je průzkum výskytu OSAS v populaci rizikově těhotných a průzkum souvislosti OSAS s rizikovými faktory pro těhotenství.

Charakteristika souboru: Ze 480 sledovaných těhotných bylo zkoumáno 85 a do studie zařazeno 61 rizikově těhotných respondentek.

Metody: Statisticky jsme zhodnotili vztah OSAS k hypertenzi, obezitě, preeklamptickým změnám placenty, nízkému pH pupečníkové krve, nízké hladině $\mathrm{PlGF}$ ve skupině rizikově těhotných s $\mathrm{AHI}<5$ a ve skupině $s \mathrm{AHI} \geq 5$.

Výsledky: Ve studovaném souboru byla prokázána významná statistická souvislost výskytu OSAS s gestačním diabetem a obezitou u rizikově těhotných. Nebyla prokázána souvislost s výskytem hypertenze. Pro nízký záchyt respondentek s těmito potížemi nebyla statisticky př́nosná hodnocení výskytu histomorfologických preeklamptických změn placenty, nízkého $\mathrm{pH}$ pupečníkové krve a nízké hladiny PlGF.

Kličová slova: hypertenze; obezita; OSAS; preeklampsie; rizikové těhotenství

\section{References}

1. Barbé F, Durán-Cantolla J, Sánchez-de-la-Torre M, MartínezAlonso M, Carmona C, Barceló A, et al. (2012). Effect of continuous positive airway pressure on the incidence of hypertension and cardiovascular events in nonsleepy patients with obstructive sleep apnea: a randomized controlled trial. JAMA 307(20): 2161-2168. DOI: 10.1001/jama.2012.4366.

2. Bixler EO, Vgontzas AN, Lin HM, Ten Have T, Rein J, VelaBueno A, et al. (2001). Prevalence of sleep-disordered breathing in women: effects of gender. Am J Respir Crit Care Med 163(3): 608-613. DOI: 10.1164/ajrccm.163.3.9911064.

3. Bourjeily G, Raker CA, Chalhoub M, Miller MA (2010). Pregnancy and fetal outcomes of symptoms of sleepdisordered breathing. Eur Respir J 36(4): 849-855. DOI: 10.1183/09031936.00021810.

4. Champagne K, Schwartzman K, Opatrny L, Barriga P, Morin L, Mallozzi A, et al. (2009). Obstructive sleep apnoea and its association with gestational hypertension. Eur Respir J 33(3): 559-65. DOI: 10.1183/09031936.00122607.

5. Cho JW, Duffy JF (2017). Sleep, sleep disorders, and sexual dysfunction. World J Mens Health 45(7): 503-508. DOI: $10.5534 /$ wjmh. 180045.

6. Duley L (2009). The global impact of pre-eclampsia and eclampsia. Semin Perinatol 33(3): 130-137. DOI: 10.1053/j. semperi.2009.02.010.

7. Högberg U (2005). The world health report 2005: "Make every mother and child count" - including Africans. Scand J Public Health 33(6): 409-411. DOI: 10.1080/14034940500217037

8. Izci B, Martin SE, Dundas KC, Liston WA, Calder AA, Douglas NJ (2005). Sleep complaints: snoring and daytime sleepiness in pregnant and pre-eclamptic women. Sleep Med 6(2): 163-169. DOI: 10.1016/j.sleep.2004.12.007.

9. Kasai T (2012). Sleep apnea and heart failure. J Cardiol 60(2): 78-85. DOI: 10.1016/j.jjcc.2012.05.013.

10. Liu A, Wen SW, Bottomley J, Walker MC, Smith G (2009). Utilization of health care services of pregnant women complicated by preeclampsia in Ontario. Hypertens Pregnancy 28(1): 76-84. DOI: 10.1080/10641950802366252.
11. Louis J, Auckley D, Miladinovic B, Shepherd A, Mencin P, Kumar D, et al. (2012). Perinatal outcomes associated with obstructive sleep apnea in obese pregnant women. Obstet Gynecol 120(5): 1085-1092. DOI: 10.1097/ AOG.0b013e31826eb9d8.

12. Monahan K, Redline S (2011). Role of obstructive sleep apnea in cardiovascular disease. Curr Opin Cardiol 26(6): 541-547. DOI: 10.1097/HCO.0b013e32834b806a.

13. O'Brien LM, Bullough AS, Chames MC, Shelgikar AV, Armitage R, Guilleminualt C, et al. (2014). Hypertension, snoring, and obstructive sleep apnea during pregnancy: a cohort study. BJOG 121(13): 1685-1693. DOI: 10.1111/1471 0528.12885

14. O’Brien LM, Bullough AS, Owusu JT, Tremblay KA, Brincat CA, Chames MC et al. (2012). Pregnancy-onset habitual snoring, gestational hypertension, and pre-eclampsia: prospective cohort study. Am J Obstet Gynecol 207(6): 487-489. DOI: 10.1016/j. ajog.2012.08.034.

15. Olišarová V, Šedová L, Tóthová V, Bártlová S, Chloubová I, Michálková H, et al. (2016). Areas of health-education of physicians and nurses in care for cardiac patients from the perspective of citizens of the Czech Republic. Neuroendocrinology Letters 37 (Suppl. 2): 5-10.

16. Olivarez SA, Ferres M, Antony K, Mattewal A, Maheshwari B, Sangi-Haghpeykar H, et al. (2011). Obstructive sleep apnea screening in pregnancy, perinatal outcomes, and impact of maternal obesity. Am J Perinatol 28(8): 651-658. DOI: $10.1055 / \mathrm{s}-0031-1276740$.

17. Pien GW, Fife D, Pack AI, Nkwuo JE, Schwab RJ (2005). Changes in symptoms of sleep-disordered breathing during pregnancy. Sleep 28(10): 1299-305. DOI: 10.1093/ sleep/28.10.1299.

18. Polo-Kantola P, Rauhala E, Helenius H, Erkkola R, Irjala K, Polo O (2003). Breathing during sleep in menopause: a randomized, controlled, crossover trial with estrogen therapy. Obstet Gynecol 102(1): 68-75. DOI: 10.1016/S00297844(03)00374-0.

19. Redline S, Kump K, Tishler PV, Browner I, Ferrette V (1994). Gender differences in sleep disordered breathing in a community-based sample. Am J Respir Crit Care Med 149 (3 Pt 1): 722-726. DOI: 10.1164/ajrccm.149.3.8118642. 
20. Reid J, Skomro R, Cotton D, Ward H, Olatunbosun F, Gjevre J, et al. (2011). Pregnant women with gestational hypertension may have a high frequency of sleep disordered breathing. Sleep 34(8): 1033-1038. DOI: 10.5665/SLEEP.1156.

21. Reutrakul J, Zaidi N, Wroblewski K, Kay HH, Ismail M, Ehrmann DA, et al. (2013). Interactions between pregnancy, obstructive sleep apnea, and gestational diabetes mellitus. J Clin Endocrinol Metab 98(10): 4195-4202. DOI: 10.1210/ jc.2013-2348.

22. Shipley JE, Schteingart DE, Tandom R, Starkman MN (1992). Sleep architecture and sleep apnea in patients with Cushing's disease. Sleep 15(6): 514-518. DOI: 10.1093/sleep/15.6.514.

23. Slouka D, Holoubková J, Frei J (2015). Obstrukční syndrom spánkové apnoe. In: Slouka D (Ed.). Syndrom spánkové apnoe. Plzeň: Euroverlag, pp. 55-71.

24. Slouka D, Honnerova M, Hosek P, Matas A, Slama K, Landsmanova, J, et al. (2018). Risk factors for failure of continuous positive airway pressure treatment in patients with obstructive sleep apnoea. Biomed Pap Med 162(2): 134-138. DOI: 10.5507/bp.2017.056.

25. Slouka D, Honnerova M, Hrabe V, Matas A (2014). The prediction of treatment failure of the continuous positive airways pressure. Bratisl Lek Listy 115(11): 704-707.

26. Sonka K, Nevšímalová S (2011). 60 years of sleep medicine at the Department of Neurology, First Faculty of Medicine, Charles University in Prague and General University Hospital in Prague. Prague Med Rep 112(3): 236-243.

27. Spence R, Allen RC, Lutgendorf MA, Gary VR, Richard JD, Gonzalez SC (2017). Association of obstructive sleep apnea with adverse pregnancy-related outcomes in military hospitals. Eur J Obstet Gynecol Reprod Biol 210: 166-172. DOI: 10.1016/j. ejogrb.2016.12.013.
28. Tanaka A, Inaguma D, Ito E, Kamegai N, Kato A, Mizutani M, et al. (2017). Factors associated with severity of sleep apnoea syndrome in patients with chronic kidney disease. Acta Cardiol 72(4): 440-445. DOI: 10.1080/00015385.2017.1335048.

29. Townsend R, Khalil A, Premakumar Y, Allotey J, Snell KIE, Chan C, et al. (2016). Prediction of pre-eclampsia: review of reviews. Ultrasound Obstet Gynecol 29(8): 542-546. DOI: 10.1002/uog.20117.

30. Tsuda K (2017). Associations among sodium intake, endothelial dysfunction and endothelial damage biomarkers in hypertension. Am J Hypertens 85(3): e8. DOI: 10.1093/ajh/ hpy141

31. Ursavas A, Karadag M, Nalci N, Ercan I, Gozu RO (2008). Self-reported snoring, maternal obesity and neck circumference as risk factors for pregnancy-induced hypertension and preeclampsia. Respiration 76(1): 33-39. DOI: $10.1159 / 000107735$

32. WHO (1999). International society of hypertension guidelines for the management of hypertension. J Hypertens 17(2): 151-183.

33. Xu JH, Li WY, Jin HY, Ye Y, Wang W (2018). Effect of serum growth hormone releasing hormone levels on cognitive function in patients with moderate-severe obstructive sleep apneahypopnea syndrome. Zhonghua Jie He He Hu Xi Za Zhi 41(8): 606-609. DOI: 10.3760/cma.j.issn.1001-0939.2018.08.007.

34. Young T (1993). Analytic epidemiology studies of sleep disordered breathing - what explains the gender difference in sleep disordered breathing? Sleep 16 (Suppl. 8): S1-S2. DOI: 10.1093/sleep/16.suppl_8.S1. 